\title{
Sensitivity of maize to herbicides in experiments in Martonvásár in 2015
}

\author{
Péter Bónis - Tamás Árendás - Csaba Szőke - Eszter Sugár - Nándor Fodor - Éva Darkó - Lajos \\ Csaba Marton \\ Agricultural Institute, Centre for Agricultural Research, Martonvásár, Hungary \\ bonis.peter@agrar.mta.hu
}

\begin{abstract}
SUMMARY
The phytotoxic effect of herbicides applied post-emergence was investigated in a herbicide sensitivity experiment set up on parental maize genotypes in Martonvásár. A total of 48 Martonvásár inbred lines and 12 single line crosses were included in small-plot experiments set up in two replications. Ten herbicides were applied at the normal authorised rate and at twice this quantity. Compounds intended for preemergence application were applied when maize was in the 3-4-leaf stage and post-emergence herbicides in the 7-8-leaf stage of development. The extent of phytotoxicity was scored two weeks after treatment. Some of the herbicides tested are not authorised for use in seed production fields, but it is important to know how the parental genotypes respond to all types of herbicides. Phytotoxic symptoms of varying intensity were only observed on a third of the 60 parental genotypes examined; the majority of the lines exhibited no reaction to any of the herbicides. Averaged over the 60 genotypes the level of phytotoxic damage was less than 10\% for the single dose. When the double dose was applied somewhat more severe damage was induced by products containing Mesotrione + Nicosulfuron or Foramsulfuron + Isoxadifen-ethyl, but this was still below 15\%. The herbicide dose had a three times stronger influence on the intensity of the symptoms than the type of herbicide. With the exception of Topramezone, there was a significant difference between the effects of the normal and double doses. The greatest dose effect differences, in decreasing order, were observed for Mesotrione + Nicosulfuron, Foramsulfuron + Isoxadifenethyl. Nicosulfuron and Mesotrione + Terbutylazine. The Mesotrione + Terbutylazine active ingredient combination only caused mild ( $<10 \%)$ symptoms on a total of 11 genotypes, while the Mesotrione + Nicosulfuron combination induced more severe phytotoxic symptoms on 26 lines. When Nicosulfuron was applied alone it caused milder symptoms on fewer genotypes than in combination with Mesotrione. Among compounds of the sulphonyl-urea type, the least severe symptoms on the fewest genotypes were recorded in the case of Prosulfuron.
\end{abstract}

Keywords: maize inbred lines, post-emergence herbicide, phytotoxicity

\section{INTRODUCTION}

Chemical weed control has a key importance for large-scale maize production. Only a few of the many herbicides available to maize growers can be safely used for weed control of inbred lines. Numerous studies have demonstrated the diverse levels of herbicide tolerance of maize lines (Shimabukuro et al., 1971, Eberlein et al., 1989; Harms et al., 1990; Kang, 1993; Widstrom and Dowler, 1995; Green and Ulrich, 1993, 1994; Green, 1998; Bónis et al., 2004, 2013). The interaction between herbicide and crop is influenced not only by the active ingredient - genotype relationship but also by the year and by other environmental factors (Berzsenyi et al., 1997; Bónis et al., 2011).

\section{MATERIALS AND METHODS}

A small-plot field experiment was set up in two replications in Martonvásár on chernozem soil with forest residues to investigate the herbicide tolerance of maize genotypes bred in Martonvásár.

The phytotoxic effects of ten herbicides (Table 1), applied post-emergence with a plot sprayer at the authorised dose and at twice this quantity, were examined for 48 Martonvásár inbred lines and 12 single line crosses. For experimental purposes, compounds intended for pre-emergence use were also applied postemergence when the maize plants were in the 3-4-leaf stage (Treatments 1 and 2).

The post-emergence herbicides were applied when the maize was in the 7-8-leaf stage and the level of phytotoxicity was evaluated on a 0-100 scale 14 days after treatment. Each herbicide had its own untreated control. The treatments are listed in Table 1. Some of the herbicides tested are not authorised for use in seed production fields. These were the following: Isoxaflutole + Cyprosulfamide (Treatment 2), Nicosulfuron (7), though this active ingredient is authorised in some combinations, Topramezone + Dicamba (9) and Foramsulfuron + Isoxadifen-ethyl (10). It is important, however, to study the reactions of parental genotypes to all types of herbicides in order to prepare for the possibility of extreme cases where the level of weed infestation makes it imperative to apply them. 
Treatments applied in the herbicide tolerance experiment, Martonvásár 2015

\begin{tabular}{|c|l|c|c|}
\hline \multirow{2}{*}{ Treatment } & \multicolumn{2}{c|}{ Dose (ml, g a.i. ha- ${ }^{1}$ ) } \\
\cline { 3 - 4 } & & Normal & Double \\
\hline & Control & - & - \\
\hline 1 & Mesotrione + S-metolachlor + Terbutylazine & $187.5+1875+625$ & $375+3750+1250$ \\
\hline 2 & Isoxaflutole + Cyprosulfamide & $105.6+105.6$ & $211.2+211.2$ \\
\hline 3 & Topramezone & 50.4 & 100.8 \\
\hline 4 & Mesotrione + Terbutylazine & $115+749.8$ & $230+1499.6$ \\
\hline 5 & Tembotrione + Isoxidifen-ethyl & $99+47.5$ & $198+99$ \\
\hline 6 & Mesotrione + Nicosulfuron & $150+60$ & $300+120$ \\
\hline 7 & Nicosulfuron & 48 & 96 \\
\hline 8 & Prosulfuron & 15 & 30 \\
\hline 9 & Topramezone + Dicamba & $50+160$ & $100+320$ \\
\hline 10 & Foramsulfuron + Isoxadifen-ethyl & $56.25+56.25$ & $112.5+112.5$ \\
\hline
\end{tabular}

The weather in the 2015 growing season was characterised by rainfall deficiency. Up to the end of August, almost $100 \mathrm{~mm}$ less rain fell during the growing season than the 30-year mean. In June there was only $29 \mathrm{~mm}$ rainfall, which was less than half the 30-year mean $(73 \mathrm{~mm})$. The most important weather data for the spraying period are illustrated in Figure 1.

On June $3^{\text {rd }}$, when the pre-emergence herbicides were applied to maize plants in the 3-4-leaf stage, the daily mean temperature was close to $25^{\circ} \mathrm{C}$, with a maximum of over $30^{\circ} \mathrm{C}$. The $23 \mathrm{~mm}$ rain that fell within a week of the treatment facilitated the uptake of the herbicides through the roots. When the post-emergence herbicides were sprayed on June $16^{\text {th }}$ and on the following days the daily mean temperature was less than $20^{\circ} \mathrm{C}$ and even the maximum temperatures were below $25^{\circ} \mathrm{C}$ (Figure 1).

Figure 1: Major weather parameters at spraying and over the following days. Martonvásár, June 2015

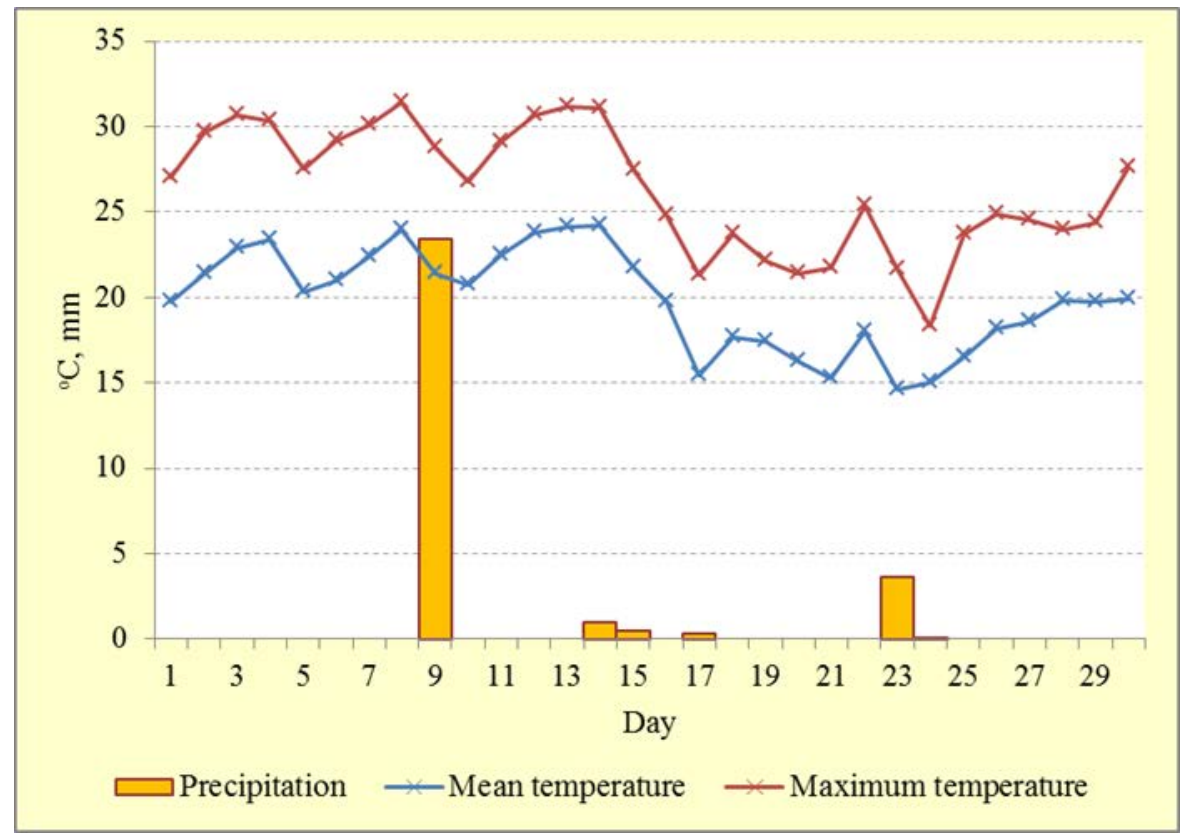

Scoring results were evaluated using two-factor analysis of variance (ANOVA).

\section{RESULTS}

Averaged over the 60 genotypes the extent of phytotoxic damage did not exceed $10 \%$ for the single doses, while the double doses of Treatments 6 and 10 (Mesotrione + Nicosulfuron and Foramsulfuron + Isoxadifenethyl) caused more severe damage, but still below 15\% (Figure 2). Analysis of variance revealed highly significant differences (at the $\mathrm{F}=0.1 \%$ level) between both the herbicide and dose effects. Based on the MQ values (not shown) the herbicide dose influenced the intensity of the symptoms three times more than the type of 
herbicide ( $\mathrm{MQ}=121.2$ and $\mathrm{MQ}=40.71$, respectively). Among the treatments, only for Treatment 3 (Topramezone) was there no significant difference between the normal and double doses (Table 2). The greatest differences in the dose effects were found in decreasing order for Treatments 6 (Mesotrione + Nicosulfuron, 8.81\%), 10 (Foramsulfuron + Isoxadifen-ethyl, 8.80\%), 7 (Nicosulfuron, 5.97\%) and 4 (Mesotrione + Terbutylazine, 4.28\%). Averaged over the genotypes, phytotoxic damage of below 1\% was observed for the single doses of Treatments 1 (Mesotrione + S-metolachlor + Terbutylazine), 2 (Isoxaflutole + Cyprosulfamide), 3 (Topramezone), 8 (Prosulfuron) and 9 (Topramezone + Dicamba). The level of phytotoxicity was between 1 and 3\% for Treatments 4 (Mesotrione + Terbutylazine), 5 (Tembotrione + Isoxadifen-ethyl) and 7 (Nicosulfuron), and above 3\% for Treatments 6 (Mesotrione + Nicosulfuron) and 10 (Foramsulfuron + Isoxadifen-ethyl).

Figure 2: Visible phytotoxic effects (\%) of normal and double doses of herbicides two weeks after treatment in a maize herbicide tolerance experiment, averaged over 60 genotypes. Martonvásár, 2015

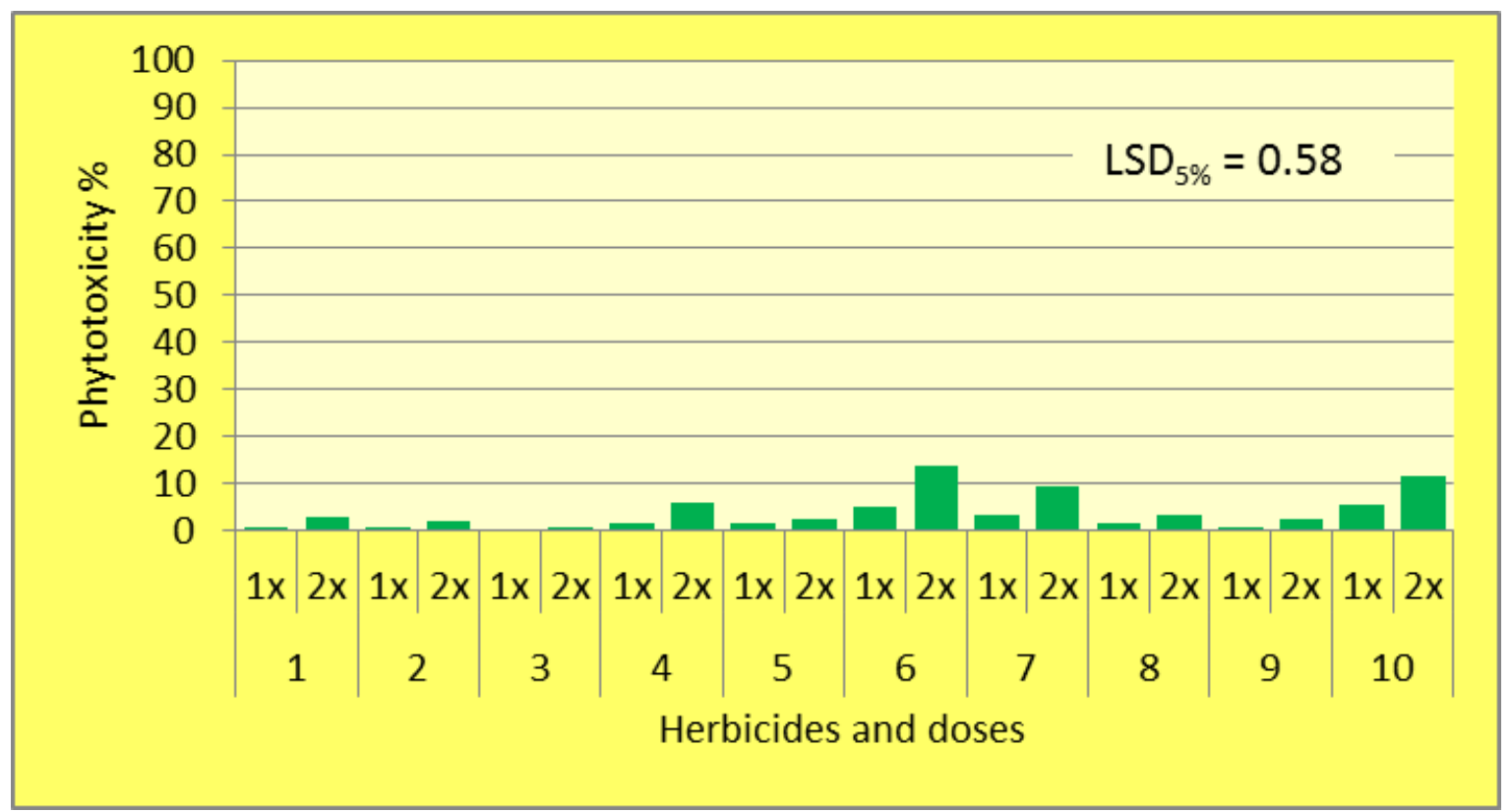

\begin{tabular}{|c|c|c|c|c|}
\hline \multirow{2}{*}{ Herbicide } & \multicolumn{2}{|c|}{ Dose } & \multirow{2}{*}{ Mean } & \multirow{2}{*}{$\mathrm{LSD}_{5 \%}$} \\
\hline & $1 \mathrm{x}$ & $2 x$ & & \\
\hline 1 & 0.60 & 2.31 & 1.46 & \multirow{10}{*}{0.39} \\
\hline 2 & 0.56 & 2.27 & 1.41 & \\
\hline 3 & 0.00 & 0.55 & 0.28 & \\
\hline 4 & 1.48 & 5.76 & 3.62 & \\
\hline 5 & 1.27 & 2.33 & 1.80 & \\
\hline 6 & 5.00 & 13.81 & 9.41 & \\
\hline 7 & 2.75 & 8.73 & 5.74 & \\
\hline 8 & 0.97 & 2.92 & 1.95 & \\
\hline 9 & 0.25 & 2.22 & 1.24 & \\
\hline 10 & 4.83 & 11.62 & 8.23 & \\
\hline Mean & 1.77 & 5.25 & 3.51 & 0.23 \\
\hline $\mathrm{LSD}_{5 \% \text { between any treatments }}$ & \multicolumn{2}{|c|}{0.58} & & \\
\hline
\end{tabular}

The genotypes on which the normal herbicide doses exerted phytotoxic effects are shown in Figures 3-9. As can be seen in Figures 3 and 4, the two pre-emergence herbicides (Mesotrione + S-metolachlor + Terbutylazine and Isoxaflutole + Cyprosulfamide), applied when maize was in the 3-4-leaf stage, both caused mild yellowing symptoms on five different genotypes, but these disappeared later as the maize plants developed. 
Figure 3: Effect of treatment with the normal dose of the pre-emergence herbicide Mesotrione + S-metolachlor + Terbutylazine in the 3-4-leaf stage of maize, averaged over 60 parental genotypes from Martonvásár

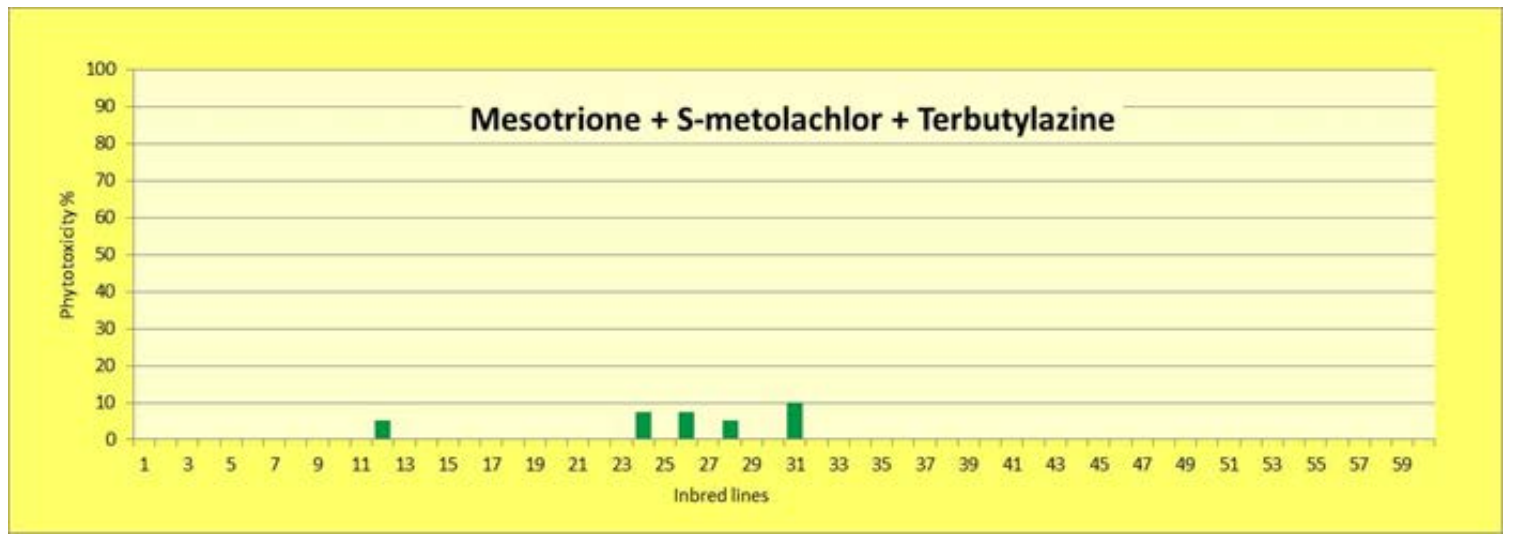

Figure 4: Effect of treatment with the normal dose of the pre-emergence herbicide Isoxaflutole + Cyprosulfamide in the 3-4-leaf stage of maize, averaged over 60 parental genotypes from Martonvásár

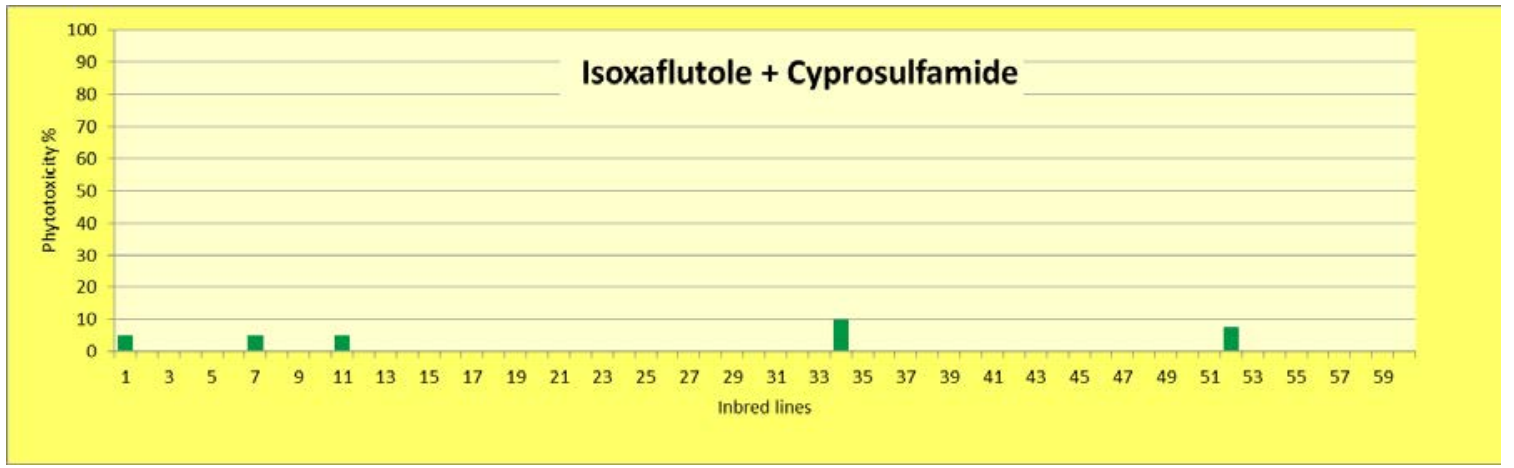

Among the post-emergence herbicides sprayed in the 7-8-leaf stage, Topramezone (Treatment 3) caused no symptoms on any of the lines, while Topramezone + Dicamba (Treatment 9) only led to very mild initial damage on two genotypes and Tembotrione + Isoxadifen-ethyl (Treatment 5) only produced intensive symptoms (around $40 \%$ ) on two extremely herbicide-sensitive lines. (These results are not presented in separate figures.)

The active ingredient Mesotrione, a component in one of the pre-emergence herbicides, was also included in the experiment in two post-emergence combinations, the results of which are illustrated in Figures 5 and 6.

Figure 5: Effect of the normal dose of Mesotrione + Terbutylazine applied in the 7-8-leaf stage of maize, averaged over 60 parental genotypes from Martonvásár

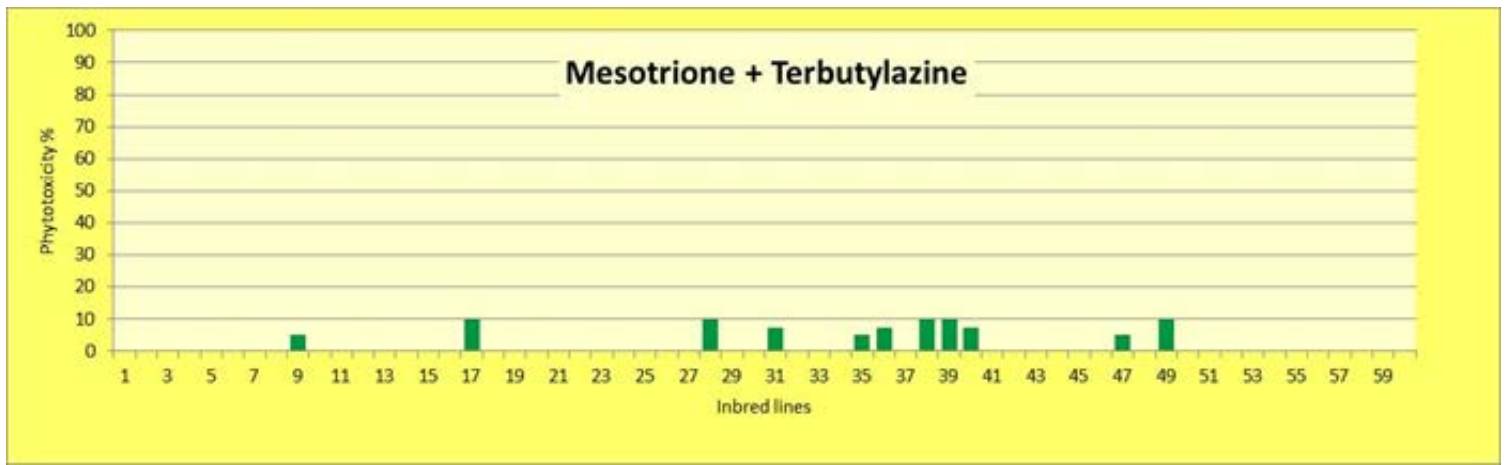


Figure 6: Effect of the normal dose of Mesotrione + Nicosulfuron applied in the 7-8-leaf stage of maize, averaged over 60 parental genotypes from Martonvásár

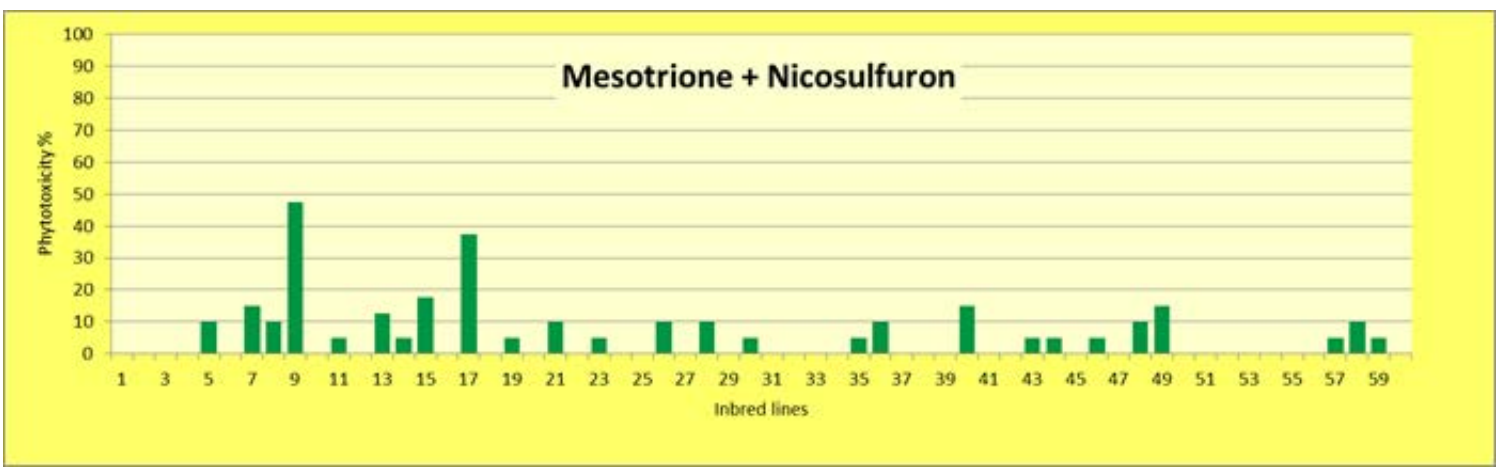

The Mesotrione + Terbutylazine combination only caused mild symptoms on a total of 11 genotypes, while the effect of the Mesotrione + Nicosulfuron could be observed as more severe phytotoxic symptoms on 26 of the lines. When Nicosulfuron was applied alone (Treatment 7) it produced milder symptoms on fewer genotypes than when combined with Mesotrione (Figure 6 and 7).

Figure 7: Effect of the normal dose of Nicosulfuron applied in the 7-8-leaf stage of maize, averaged over 60 parental genotypes from Martonvásár

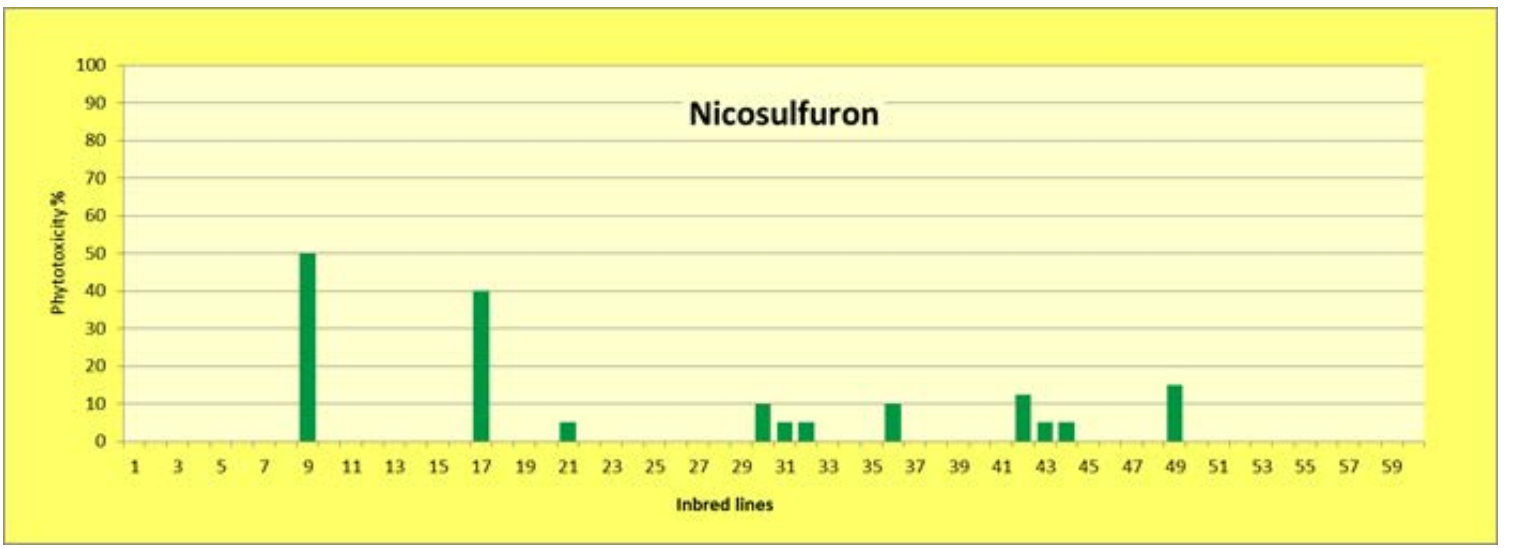

Among the compounds of the sulphonamide-urea type (Nicosulfuron, Prosulfuron, Foramsulfuron + Isoxadifen-ethyl), Prosulfuron produced the least damage on the lowest number of genotypes. Altogether, Foramsulfuron + Isoxadifen-ethyl caused visible phytotoxic symptoms of varying intensity on 23 genotypes, Nicosulfuron on 11 and Prosulfuron on four (Figure 7-9).

Figure 8: Effect of the normal dose of Prosulfuron applied in the 7-8-leaf stage of maize, averaged over 60 parental genotypes from Martonvásár

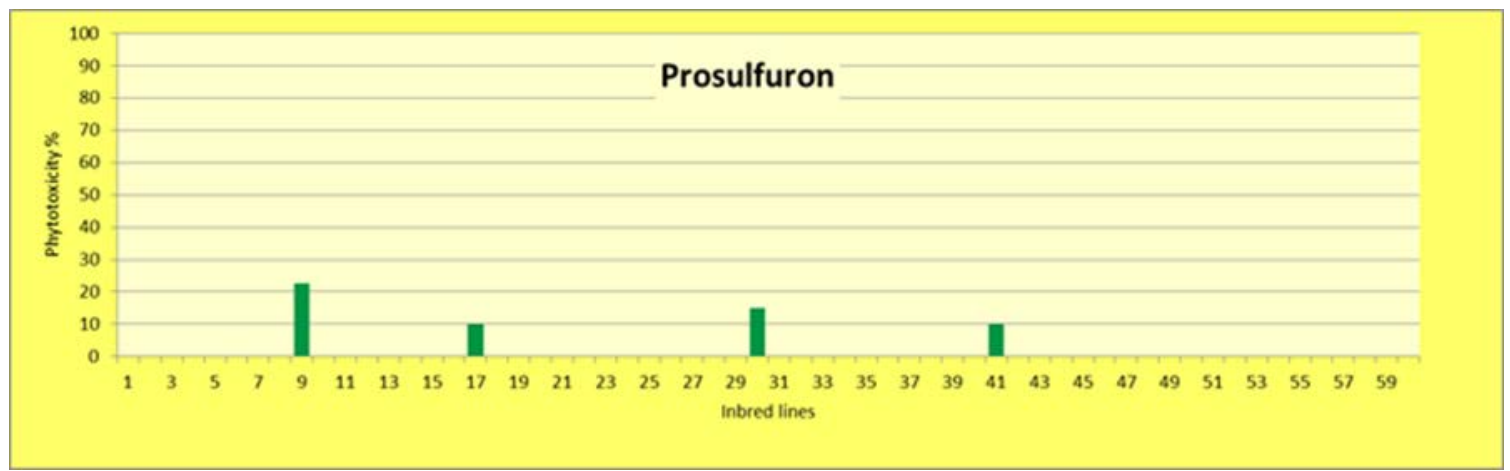


Figure 9: Effect of the normal dose of Foramsulfuron + Isoxadifen-ethyl applied in the 7-8-leaf stage of maize, averaged over 60 parental genotypes from Martonvásár

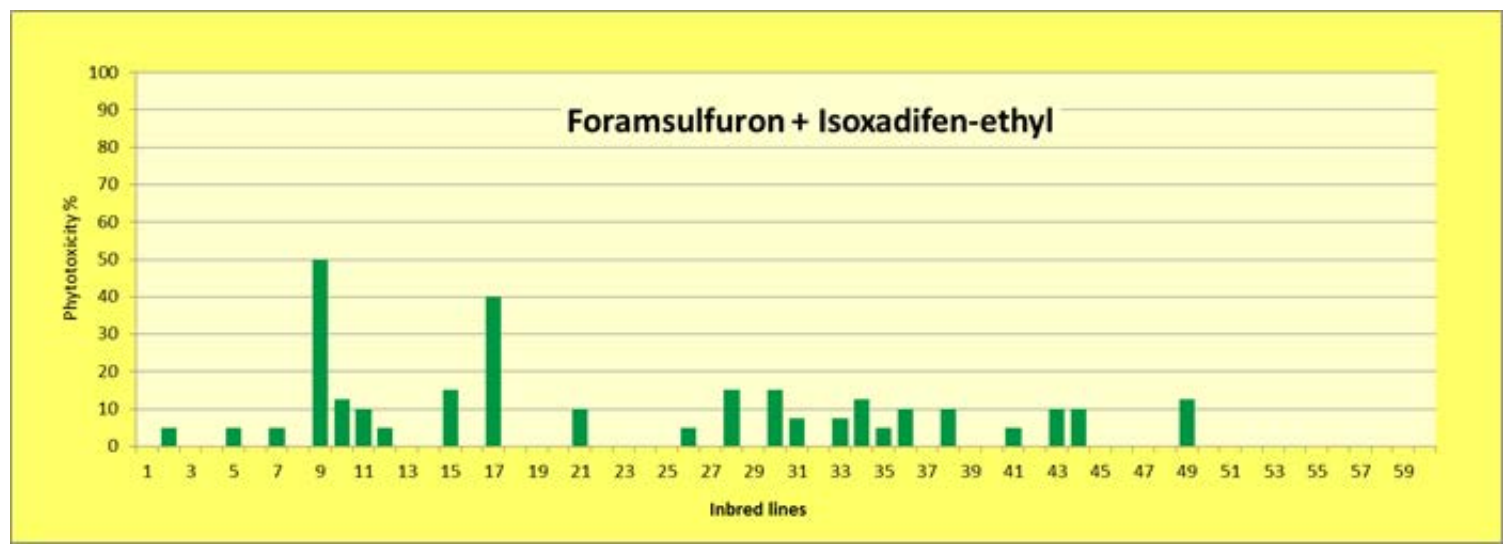

\section{DISCUSSION}

Only a third of the 60 parental genotypes from Martonvásár exhibited symptoms of varying intensity, while the majority did not react to any of the herbicide treatments. Averaged over the 60 genotypes, the phytotoxic damage did not exceed $10 \%$ in the case of the single dose, while the double quantity only caused more severe symptoms in the case of Mesotrione + Nicosulfuron and Foramsulfuron + Isoxadifenethyl, but even then the damage level was below $15 \%$.

Analysis of variance indicated that the herbicide dose had three times as strong an influence on the severity of the symptoms as the type of herbicide. Among the treatments, only for Treatment 3 (Topramezone) was there no significant difference between the effects of the normal and double doses. The greatest dose effect differences were recorded in decreasing order for Mesotrione + Nicosulfuron, Foramsulfuron + Isoxadifen-ethyl, Nicosulfuron and Mesotrione + Terbutylazine.

The Mesotrione + Terbutylazine combination only caused mild $(<10 \%)$ symptoms on a total of 11 genotypes, while the Mesotrione + Nicosulfuron combination caused more severe phytotoxicity on 26 lines. When applied alone, Nicosulfuron induced milder symptoms on fewer genotypes than in combination with Mesotrione.

Among the compounds of the sulphonamide-urea type, Prosulfuron caused the least damage on the lowest number of genotypes.

\section{REFERENCES}

Berzsenyi, Z. - Győrffy, B. - Árendás, T. - Bónis, P. - Lap, D. Q. (1997): Studies on the phytotoxicity of herbicides in maize (Zea mays L.) as affected by temperature and antidotes. Acta Agron. Hung. 45, 443-448.

Bónis, P. - Árendás, T. - Berzsenyi, Z. - Marton, L. C. (2004): Herbicide tolerance studies on maize inbred lines. Z. PflKrankh. PlfSchutz, Sonderh. 19, 901-907.

Bónis, P. - Árendás, T. - Berzsenyi, Z. - Marton L. C. (2011): Kukorica genotípusok herbicid toleranciájának változása aszályos és csapadékos évjáratokban. Changes in the herbicide tolerance of maize genotypes in wet and dry years. Acta Agraria Debreceniensis 43, 124-127.

Bónis, P. - Árendás, T. - Szőke, C. - Micskei G. - Marton L. C. (2013): Posztemergens kukorica gyomirtó szerek fitotoxikus hatása kukorica törzsekre rendkívül aszályos évjáratban. (Phytotoxic effect of post-emergence herbicides on maize line sin an extremely dry year.) Agrártudományi Közlemények 53, 71-74.

Eberlein, C.V. - Rosow, K. M. - Geadelmann, J. L. - Openshaw, S. J. (1989): Differential tolerance of corn genotypes to DPX-M6316. Weed Sci. 37, 651-657.

Green, J. M. (1998): Differential tolerance of corn (Zea mays) inbreds to four sulfonylurea herbicides and bentazon. Weed Technology 12, 474-477.

Green, J. M. - Ulrich, J. F. (1993): Response of corn (Zea mays) inbreds and hybrids to sulfonylurea herbicides. Weed Science 41, 508-516.

Green, J. M. - Ulrich, J. F. (1994): Response of maize (Zea mays) inbreds and hybrids to rimsulfuron. Pestic. Science 40, 187-191.

Harms, C. T. - Montoya, A. L. - Privalle, L. S. - Riggs, R. W. (1990): Genetic and biochemical characterization of corn inbred lines tolerant to sulfonylurea herbicide primisulfuron. Theor. Appl. Genet. 80, 353-358.

Kang, M. S. (1993): Inheritance of susceptibility of nicosulfuron herbicide in maize. J. Heredity 84, 216-217.

Shimabukuro, R. H. - Frear, D. S. - Swanson, H. R. - Walsh, W. C. (1971): Glutathione conjugation - an enzymatic basis for atrazine resistance in corn. Plant Physiology 47, 10-14.

Widstrom, N. W. - Dowler C. D. (1995): Sensitivity of selected field corn (Zea mays) to nicosulfuron. Weed Technology 9, 779-782. 